\title{
チリ地震津波発生時における岩手県内の避難行動に関する アンケート調査結果
}

\author{
On Evacuation Behavior in Iwate at 2010 Chile Earthquake Tsunami
}

\begin{abstract}
吉田健 ${ }^{1} \cdot$ 松林由里子 $^{2} \cdot$ 小笠原敏記 $^{3} \cdot$ 堺 茂樹 ${ }^{4}$
Kenichi YOSHIDA, Yuriko MATSUBAYASHI, Toshinori OGASAWARA and Shigeki SAKAI

Chile Earthquake Tsunami hit the coastal area of Japan 28 Feb. 2010. In coastal area of Iwate prefecture, an evacuation order was issued and it's reported that only $12.2 \%$ of residents had evacuated to the evacuation centers. In order to investigate the evacuation behavior, we carried out the questionnaire survey. The result of questionnaire revealed that (1) Over $60 \%$ evacuated respondents went not to the evacuation centers, but to relatives, etc. (2) About $70 \%$ respondents went back home before the evacuation order was lifted. (3) Presence of disaster-prevention facility can lower motivation to evacuate. (4) Nearly $20 \%$ respondents answered that they will evacuate immediately when next Sanriku earthquake occur.
\end{abstract}

\section{1. はじめに}

2010 年 2 月 27 日南米チリ中部沖で発生した地震によ り, 28 日9時33分, 岩手県では $3 \mathrm{~m}$ 以上の津波が予想さ れる大津波警報が初めて発令された（図-1). その後, 19 時 1 分に津波警報，3月1日1時7分に津波注意報へと切 り替わり，10時 15 分に解除された。岩手県沿岸の 12 市 町村では避難指示を発令し, 住民に対して津波の襲来の 周知・避難の呼び掛けを行った。しかしながら，2010年 3 月に実施された総務省消防庁による避難実態調査によ ると, 指定避難場所で確認された避難率は, 全国の平均 值が $7.5 \%$ であり，津波常襲地帯の岩手県沿岸であって も避難指示が発令された約 8 万 3 千人 $(31,635$ 世帯 $)$ の避 難率が $12.2 \%$ (約 1 万人) であった. 30 年以内に発生す るであろう M7.5 前後の宮城県沖地震の確率が $99 \%$ とい う評価結果のもと, 各自治体や町内会（自主防災組織） などが津波に対する啓蒙活動・避難対策を行っている現 状を考えても，高いとは言えない結果であった。

そこで本研究では，2010年チリ地震による津波来襲時 の避難行動について, 岩手県沿岸12市町村の住民を対象 としたアンケート調査を実施し, 津波発生時の避難行動 の実態を把握するとともに, 避難行動に必要な要因を明 らかにし，改善策を検討する。

\section{2. アンケート調査の概要}

アンケート対象世帯は, 岩手県沿岸12市町村の津波予

1 学生会員 修(総合 岩手大学大学院工学研究科機械 ·社会環 政策) 境システム工学専攻

2 正会員 博(工) 岩手大学助教工学部社会環境工学科

3 正会員博(工) 岩手大学准教授工学部社会環境工学科

4 正会員工博 岩手大学教授工学部社会環境工学科
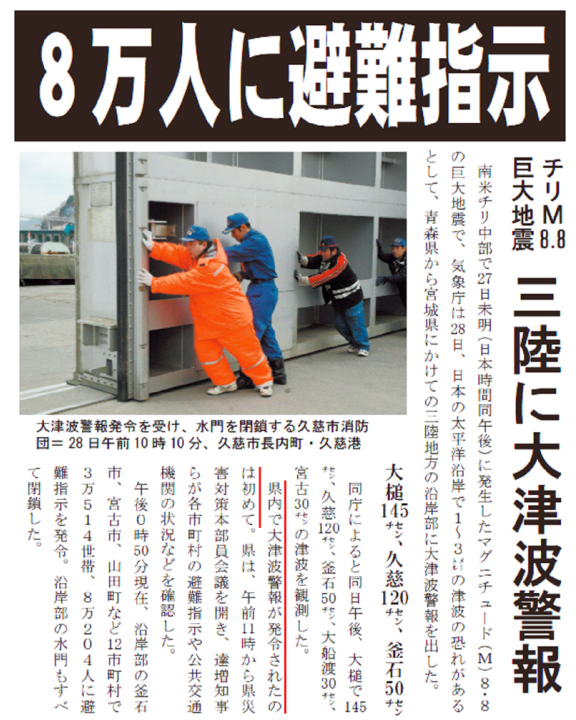

図-1 岩手県で初めて大津波警報が発令（岩手日報, 2010）

警報による避難指示・锥告の発令対象の31,635世帯から 抽出した 3,732世帯とした。調査期間は，2010年4月7日 から4月28日までとし, 岩手県から沿岸地区市町村へア ンケート調査の実施を依頼し, 各市町村にてアンケート の配布・回収を行った。回収率は70.8\% (2,635世帯) で あった。

アンケートの内容は, 図-2のフローチャートに示すよ うに, 自宅の地形的特徵, 避難の有無, 地区の防災活動 の実態, 今後の三陸沖地震津波に対する避難行動に関す る事項を全回答者に行った。さらに, 避難したと回答し た場合には，避難場所や避難場所からの帰宅時間など, 避難しなかったと回答した場合には，その主な理由に関 
する質問を行った.

\section{3. アンケート結果}

\section{（1）避難行動の有無と避難先}

図-3 は，避難行動の有無の割合を示す。「避難した」 と回答した割合は6割を上回り，消防庁が発表した岩手 県の避難率 $12.2 \%$ よも高い避難率を示した。消防庁の 示す避難率は，行政が指定する避難場所を対象としてい るため, それ以外の避難先を考慮していない. そこで, 図-4に避難先をまとめた結果を示す。避難者は，指定避 難場所の避難が 4 割未満であり, 約 6 割が近くの公共施 設や高台のように指定避難場所以外に避難していた。 た，休日であったことから親戚宅や内陸方面に向かうな ど，多様な場所で安全を確保しょうとしていることがわ かる.

図-5 は，各避難先と年齢区分の関係を示す，各世代の 回答者数は異なるが，高齢になるほど指定避難場所を避 難先として選択し，60歳以上で3割強となる。一方，若

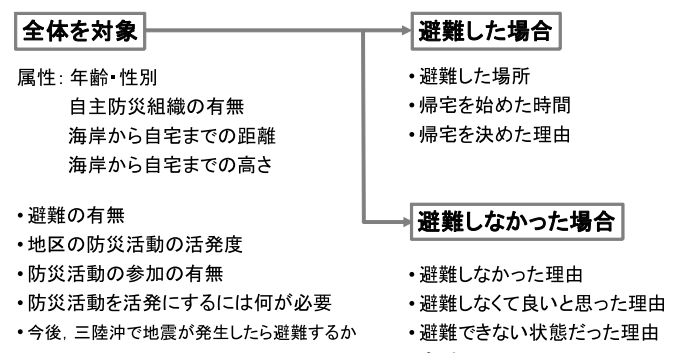
図-2 アンケート内容

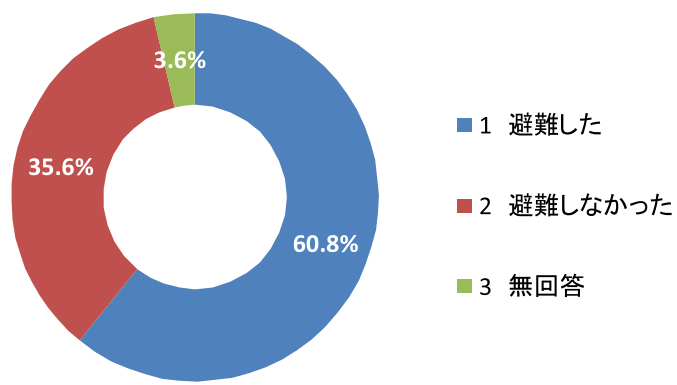

図-3 避難行動の有無

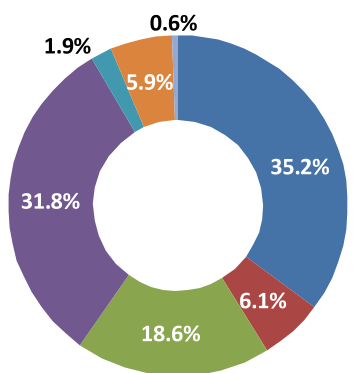

-1指定された避難場所

- 2 近くの公共施設

- 3 近くの高台

- 4 親戚·知人宅

５内陸地(盛岡方面など)

匹 6 その他

- 7 無回答

図-4 避難した割合に占める避難場所

年層になるほど親戚・知人宅などを避難先に選択し，40 歳未満で 4 割程度を占める. 40 歳未満の若い世帯は, 高 齢の世带と比較して, 指定避難場所の位置を知らないの か，地域のつながりが希薄なのか，子育て中の世帯が多 く，避難所での生活を不便に考えたのか明確に判断する ことは困難であるが，指定避難所を敬遠した事実は明白 である。

（2）避難しなかった理由

ここでは，図-3に示したように4割近くが避難をしな かったと回答していることから，その主な理由を明らか にする，図-6は，避難しなかった理由の内訳を示す，岩 手県に初めて大津波警報が発令されたにも関わらず，6 割近くが「避難しなくてもよいと思った」を，2割近く が「他地域での様子を見てから判断」を選択している. これらの回答者は, 自身の意思で避難しないことを決断 したと言える。一方，「避難できない状態だった」を選 択した回答者は，何らかの理由により自身の意に反して 避難できない状況にあったと考えられる。その理由を示 した結果を図-7に示す。主要な理由として，「自分自身 が病気，高齢であった」または，「家族が病気・高齢者 であった」を選択した割合が3割を超える結果であり， 避難行動の意志があったとしても身動きが取れない状態

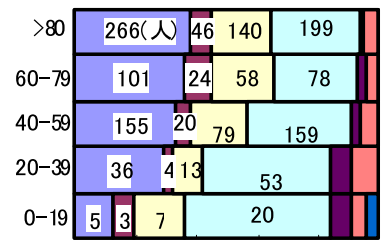

$\begin{array}{llllll}0 \% & 20 \% & 40 \% & 60 \% & 80 \% & 100 \%\end{array}$

図-5 世代別の避難先

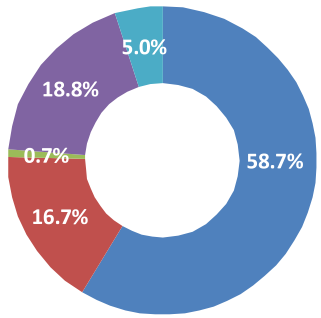

ロ 1 避難しなくて良いと思った

ロ 2 避難できない状態だった

曰 3 津波が来ることを知らなかった

ロ 4 他地域での様子を見てから判断

- 5 無回答

図-6 避難しなかった理由

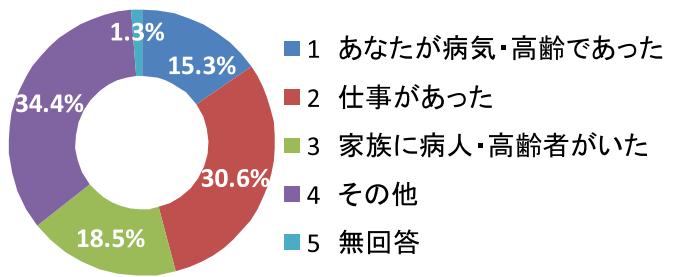

図-7 避難できなかった理由 
であったと推察される. 三陸沿岸では内陸部に比べて高 齢化が急速に進行しており, 家族だけでは避難したくて もできない事態が増えることは容易に予想される。この ような住民をどのように支援していくかが重要な課題で あるが，町内会規模のコミュニティーを活性化させ，住 民同士のネットワークを構築し，非常時に誰がどのよう な対応を行うべきなのか役割分担を明確にし，その役割 を円滑に行えるような常日頃の防災訓練が必要と考えら れる。

次に，図-6に示した「避難しなくてもよいと思った」 を選択した回答者にその理由を質問したところ，図-8に 示すような回答を得た。「自宅が高いところにある」が5 割弱と最も多く，次いで「防潮堤・防波堤等の防災施設 がある」が 2 割以上を占めている.つまり，地形的特徵 および防災施設による安心感（過信）が避難行動を妨げ る大きな要因になっていると言える.

さらに，「これまで津波の被害を受けなかった」を選 択した割合が1割を超えている．過去の津波注意報の発 令に対して，被害が小さいという経験から予警報を軽視 し，避難行動を思い留まらせたと考えられる。このよう な住民に対して, 観測機器の進歩や計算手法の改良によ って，津波の規模や到達時刻の予測精度が向上している ことを理解してもう必要がある。また，予警報の発令に よる避難行動が仮に空振りに終わったとしても，いつか 来る津波に対する円滑な避難行動の訓練と位置付けて, 率先避難者となるべき行動が大切と考えられる.

図-9は，自宅の海岸からの高さが $10 \mathrm{~m}$ 以上と答えた回 答者と, $10 \mathrm{~m}$ 未満と答えた回答者のうち，避難した人数 と避難しなかった人数を示す. 自宅の高さと避難率との 相関は高く, $10 \mathrm{~m}$ 未満の低い位置にあると回答した回答 者のうち, 約 7 割が避難しており，自宅が海岸から $10 \mathrm{~m}$

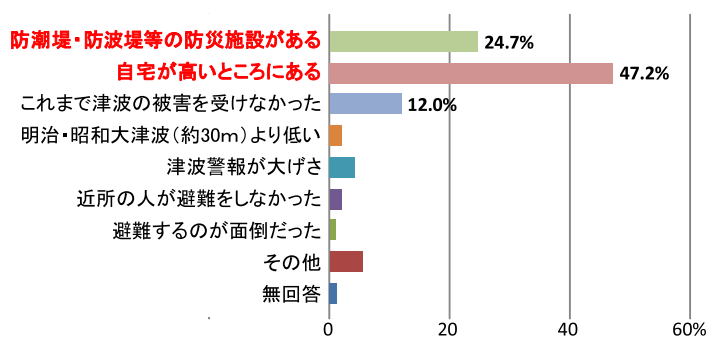

図-8避難できなかった理由

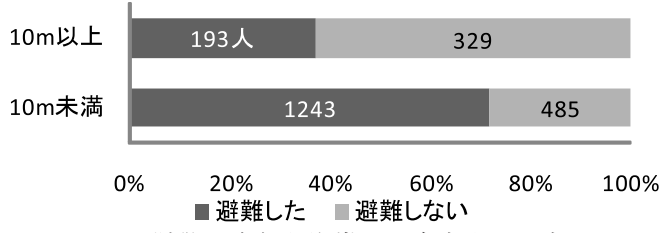

図-9避難の有無と海岸から自宅までの高さ
以上の位置にあると答えた回答者の避難率に比べて高い 傾向を示す. 回答者が主観的に判断した自宅の高さが, 津波による被災への安心感あるいは危機感に反映され， 避難行動につながっていると判断できる。ただし，この 自宅の高さは，客観的な高さではなく，回答者本人が認 識している高さであり, 実際の自宅の位置との関係は確 認できない。そのため, 回答者が安全だと考えていても, 実際に津波によって被災する可能性もあり得るし，自宅 が被災しなくても，周囲の被災により孤立することも十 分に考えられる。

浸水規模や到達時間を評価した津波シミュレーション （岩手県，2004）の結果によれば，明治・昭和三陸津波と 同規模の津波が発生した場合，岩手県沿岸に整備されて いる防潮堤や防波堤を越流する可能性が指摘されている. ハードウェアによる防災対策で全て対応することは困難 であり，ソフトウェアによる防災対策との共有が有効と 言える。 そのため, 避難指示の発令された地域では, ま ず安全な場所へ避難することが率先されるべきであり， その行動を徹底させるような啓蒙活動が求められる.

\section{（3）避難場所からの帰宅時間と帰宅した理由}

ここでは，図-3で「避難した」と答えた回答者が，避 難先から帰宅した時間帯とその理由を明らかにする.

図-10は，避難場所から帰宅を始めた時間帯の内訳を 示す。望ましい避難行動として, 津波到達の危険性が無 くなるまで避難場所に居続けることであるが，津波警報 に切り替わった時間以降の割合が 3 割程度と低く, 大津 波警報発令中である夕食の時間帯までに6割以上が帰宅 していたことがわかる．2010年チリ地震津波による最大

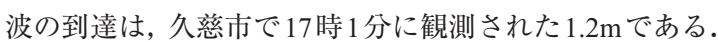
その他の観測地点でも最大波到達時刻が 17 時から 18 時 30分の間に集中していることから，帰宅途中に津波によ る被害を受ける危険性が高かったと言える.

図-11は，避難場所から帰宅した理由を示す。なお， 主な理由を3つ選択した結果である。予想津波高や到達 時刻のような情報に加え, 周囲の行動や避難場所の居心 地の悪さのような心理的感情が帰宅を促す強い要因とな っていたことがわかる. 次に，避難先と帰宅時間の関係 を図-12に示す。親戚・知人宅に避難した場合, 帰宅時

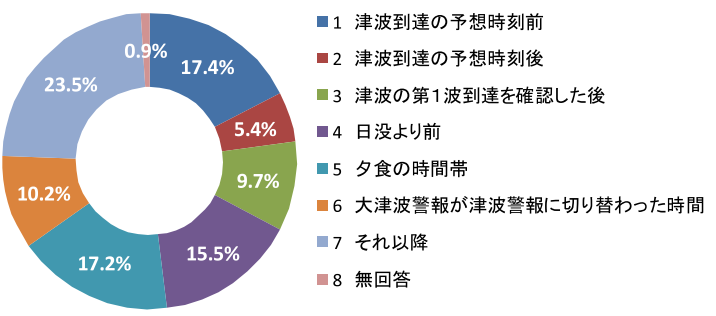

図-10＼cjkstart避難場所から帰宅を始めた時間 
間は遅いが，近くの高台に避難した場合，帰宅時間が早 くなる. 親戚・知人宅は精神的に疲れにくく, 寒さや食 事への備えもあることから長時間の避難に適していたも のと推察される.

以上より, チリ地震津波のような遠地津波の場合, 第 1 波到達後，2波目，3波目が到達するまでの時間間隔が 数時間と長くなること, 更に第 1 波が最大波とは限らな いという津波の特徵について, 避難者に周知徹底する必 要がある.さらに, 避難場所に居ても良いと思わせるよ うな環境づくりが必要であり，回答の中にもあるように 寒さや疲れ, 食事（炊き出し）などに対しては，暖房機 器や炊き出し道具を準備して置く必要があり, 常日頃の 防災活動で対応することは可能ではないだろうか.また， 親戚・知人宅の避難は, 一時避難場所として有効活用さ れる避難先の一つになる可能性がある.

\section{（4）避難行動と日ごろの防災活動の関係}

図-13 は, 避難率と地域の防災活動との関係を示す. 地域の防災活動と避難率の割合に明確な差異は見られな

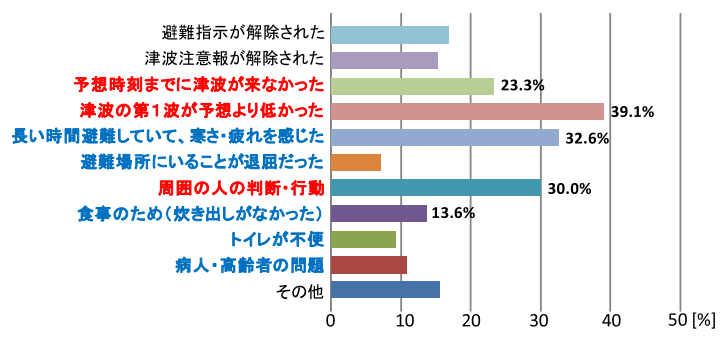

図-11避難場所から帰宅を決めた理由

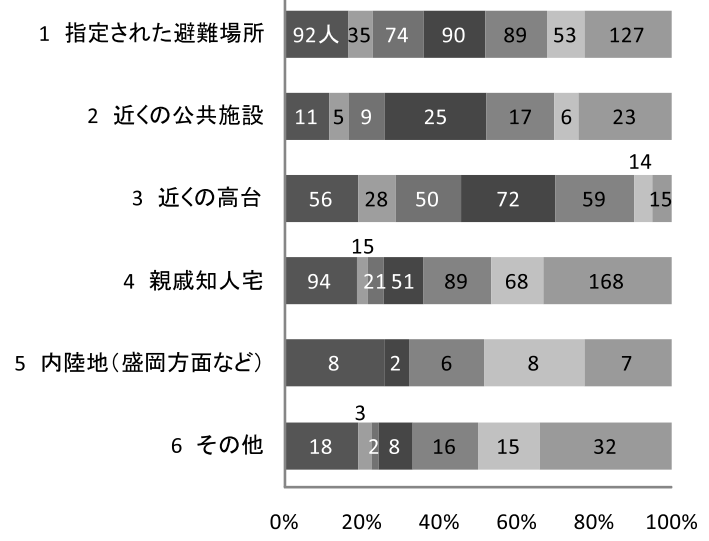

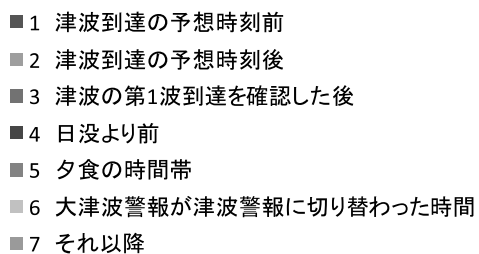

図-12 避難場所から帰宅を始めた時間と避難先の関係
い.しかし, 図-14に示すように個人の防災活動と避難 率の関係を見ると，「参加している」と回答した内の7割 強が避難していることが確認できる.つまり, 地域の防 災活動に積極的に参加すると言うことは，常日頃から防 災意識が高く，その意識が避難行動に反映されているた めと考察される.

さらに，地域の防災活動を活発にするために必要なこ とは何かと質問したところ，図-15に示すように，防災 意識の向上と回答した割合が最も多く，4割半ばであっ た。防災意識を向上させるためには，i）防災活動に対し て強力なリーダーシップを採ることができる町内会長が いること，ii）それを支える数人の若手グループがいる こと, iii）常日頃の防災活動において, 炊き出し班や救 助班のような明確な役割分担ができていることが挙げら れる。しかしながら，防災活動が大切だと認識していた としても，活動のきっかけが必要と考える住民も多く， そのためには官民学の協力が必要である.

小笠原ら（2006）は，住民参加型の津波避難を考える ワークショップを開催し, 町内会の防災活動のきっかけ として有効であることを実証している。ワークショップ は，岩手県宮古市鍬ヶ崎地区において 2005 年から 2006 年にかけて計 4 回開催し, 津波講演会の開催や, 高解像 度津波シミュレーションによる避難誘導路の検証, 実際

地域

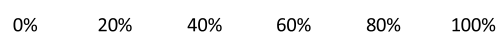

はい(活発である)

いいえ(活発でない)

わからない

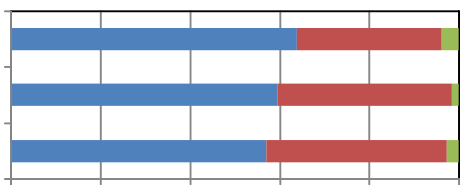

図-13 避難の有無と防災活動との関係（地域）

個人

$\begin{array}{llllll}0 \% & 20 \% & 40 \% & 60 \% & 80 \% & 100 \%\end{array}$

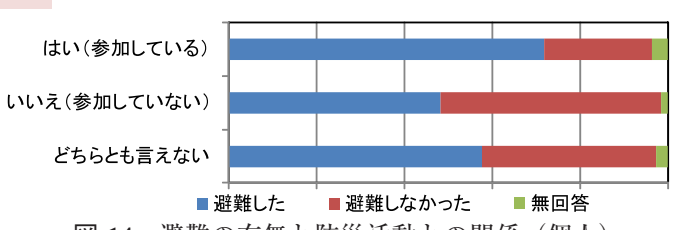

図-14 避難の有無と防災活動との関係（個人）

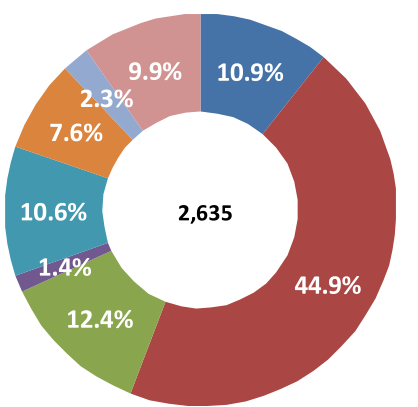

ロ 熱心なリーダー

口防災意識の向上

住民への周知

、小.中学校との連携

行政との連携

口住民参加の行事

その他

無回答

図-15防災活動を活発にするために必要なこと 


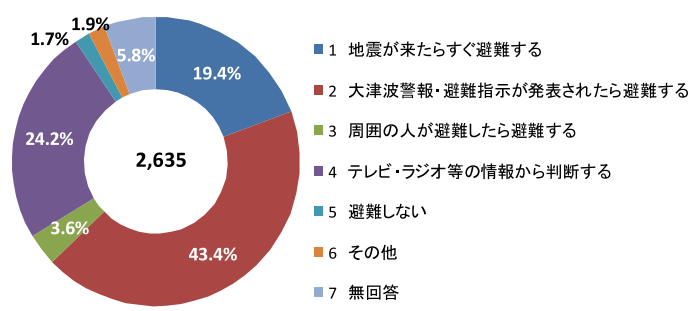

図-16 今後，三陸沖で津波が発生したときの行動

に避難路を住民と歩き, 安全性の検証などを行った。そ の結果, 最終的には住民と行政が協同で避難誘導路の整 備を行うまでに至った。また, 参加者を対象としたアン ケート調查に扔いても、9割以上が津波避難に対する意 識が高まったと回答しており，住民の防災意識が向上した。

このように，町内会などを単位とした地区ごとに，視 覚的に理解しやすい情報や資料を作成のうえ, 防災につ いて学び，考える場としてワークショップを開催するこ とは，住民の防災意識向上と地域の防災活動のきっかけ になるものと考えられる.

\section{（5）今後の避難行動}

地形的要因抒よび防災施設の存在が避難行動に大きな 影響を及ぼすことがわかったが，図-8に示すように， 「これまでに津波の被害を受けなかった」と回答してい る割合が $12.0 \%$ と比較的高く, 明治・昭和三陸津波や 1960年チリ地震津波が過去の災害として, 記憶から忘れ 去られている可能性がある. 図-16は, 今後三陸沖で津 波が発生したときの行動を示す。「地震が来たらすぐ避 難する」と回答した割合は約20\%であり，“地震＝津波” という意識が低下している. 予警報や周りの状況, テレ ビ・ラジオからの情報など避難行動を促す要因によって 初めて避難するが約 $50 \%$ と高い割合である. 将来，三陸 沖や宮城県沖で発生する津波の場合, 早い地域では 10 分 以内で津波が到達することも予想される. そのためにも,
津波に関する正しい知識を過去の被災経験も踏まえて理 解することが重要と言える.

\section{4. まとめ}

本研究では, アンケート調査により, 岩手県沿岸市町 村における2010年チリ地震津波来襲時の住民避難行動の 実態を把握し, 避難行動に関連する要因の考察を行った. 以下に, 主要な結論を列挙する.

1）避難率は $60.8 \%$ であり，住民は親戚・知人宅や近く の高台など多様な場所に避難したことが明らかとなった。

2）被災する可能性があった最大波到達時に避難場所か ら帰宅しており，津波の特徴に関する正しい防災知識 の提供と共に, 長時間の滞在に適した避難場所の環境 づくりが必要である。

3）地形的要因および防災施設の存在が避難行動を妨げ る主要な要因となっている。防災施設を越える可能性 や自宅が孤立する場合など，危険性および避難行動の 重要性を周知する必要がある.

4）三陸沖の地震津波に対して，すぐ避難するという行 動は少なく, 避難に対する意識の低下が見られる。そ のためにも過去の被災経験を踏まえた津波の現象に関 する適切な知識を学ぶ場が求められる.

\section{参 考 文 献}

岩手日報，2010年3月 1 日，朝刊， 1 面.

岩手県（2004）：岩手県地震津波シミュレーション及び被害想 定調查, http://www.pref.iwate.jp/ hp010801/tsunami/yosokuzu_ index.htm, 参照2011-03-25.

小笠原敏記・佐々木信也・堺 茂樹 - 古川 隆（2006）：自主 防災の意識向上に対する津波防災ワークショップの役割, 海岸工学論文集, 第 53卷, pp1346-1350.

内閣府・総務省（2010）：チリ中部沿岸を震源とする地震によ る津波避難に関する緊急住民アンケート調查結果につい て, http://www.bousai.go.jp/oshirase/h22/100413-1kisya.pdf, 参照2011-3-25. 